ПРОМИСЛОВЕ І ЦИВІЛЬНЕ БУДІВНИЦТВО

УДК 625.12(477)

\title{
РОЗРОБЛЕННЯ СКЛАДУ БЕТОНУ ДЛЯ МОНОЛІТНОГО БЕТОНУВАННЯ
}

\author{
Н.О. Коломієць, К.С. Гребєнщикова, канд. техн. наук С.В. Мірошніченко \\ РАЗРАБОТКА СОСТАВА БЕТОНА ДЛЯ МОНОЛИТНОГО \\ БЕТОНИРОВАНИЯ
}

\section{Н.А. Коломиец, К.С. Гребенщикова, канд. техн. наук С.В. Мирошниченко \\ DEVELOPMENT OF CONCRETE FOR MONOLITHIC CONCRETE}

\section{N.A. Kolomyjec, K.S. Hrebyenschykova, cand. of techn. scinces S.V. Miroshnichenko}

Бетон для монолітних конструкиій має відповідати вимогам тривалої міцності, повзучості й тріщиностійкості. Розглянуті теорії деформування залізобетонних конструкиій під навантаженням. Запропонована у статті методика розрахунку дозволяє підібрати оптимальний склад бетону для монолітного перекриття, виходячи 3 особливостей місиевих матеріалів.

Ключові слова: перекриття, деформачія бетону, повзучість, тріщиностійкість, монолітний залізобетон.

Бетон для монолитных конструкций должен отвечать требованиям длительной прочности, ползучести и трещзиностойкости. Рассмотрены теории деформирования железобетонных конструкций под нагрузкой. Предложенная в статье методика расчета позволяет подобрать оптимальный состав бетона для монолитного перекрытия, исходя из особенностей местных материалов.

Ключевые слова: перекрытия, деформация бетона, ползучесть, трещиностойкость, монолитный железобетон.

For monolithic concrete structures must meet the requirements of long-term strength, creep and fracture. Consideration of the theory of deformation of reinforced concrete structures under load. The proposed method of calculation in the article allows optimum composition for monolithic concrete slab, based on

Keywords: floor, concrete strain, creep, fracture toughness, reinforced concrete.

Постановка проблеми. Особливості прояву тривалої міцності, повзучості й тріщиностійкості бетону в стиснутій і розтягнутій зонах залізобетонних виробів і конструкцій, що згинаються, особливо актуальні при проектуванні й виготовленні довгомірних або тонкостінних конструкцій, до яких можна віднести монолітні перекриття.

Аналіз останніх досліджень. Виконаний аналіз експериментальних даних дозволяє зробити певний висновок. 
Міцність бетону у виробах і конструкціях, що згинаються, зокрема залізобетонних тонкостінних конструкціях, піддається одночасному впливу двох факторів: фактора часу, що зменшує міцність при розтягненні протягом тривалого часу за рахунок механізму молекулярнокінетичного зруйнування, i фактора тривалого попереднього обтиснення бетону, що збільшує короткочасну міцність бетону. 3 урахуванням цього міцність бетону у стиснутій зоні (верхня плита чи верхній пояс) у процесі тривалої експлуатації конструкції буде в основному збільшуватися, а міцність бетону в розтягнутій зоні (низ стінки балки чи нижній пояс) - знижуватися. А значить, однією 3 головних причин зниження довговічності залізобетонних виробів i конструкцій $€$ втрата тріщиностійкості бетону в розтягнутій зоні, що посилюється мимовільним зниженням міцності бетону при розтягненні. При цьому величина моменту, який перешкоджає утворенню тріщин, стає меншою, ніж величина моменту від навантаження. Головним фактором зменшення величини моменту $\epsilon$ довгочасна повзучість бетону у стиснутій зоні, яка призводить до збільшення висоти стиснутої зони $x$ i зменшення плеча моменту. Фактором, який посилює буйнівну дію довгочасної повзучості бетону, $\epsilon$ зменшення тривалої міцності бетону при розтягненні в розтягнутій зоні конструкції.

Виділення невирішених раніше частин загальної проблеми. Після того, як були винайдені нові способи будови опалубки, монолітне будівництво почало розвиватися швидкими темпами. Завдяки каркасній системі споруд, де як опори для несучих перекрить використовуються монолітні колони, в архітекторів з'явилась можливість проектувати висотні будинки всіляких конфігурацій із різним плануванням. Спорудження перекрить такого типу дозволяє надати конструкції просторову жорсткість й таким чином обійтися без зведення несучих стін.
Уся опалубка виготовляється практично однаковою для всіх типів перекрить. Конструкція являє собою стояки, несучі балки й настил. Опалубку можна встановлювати як частинами, так $\mathrm{i}$ одразу на всю площину майбутнього перекриття. Щодо якості бетону, то для роботи рекомендується використовувати марку не нижче С 20/25. Бетон заливають у підготовлену опалубку й ущільнюють за допомогою вібратора, щоб виключити утворення повітряних прошарків. Процес здійснюється швидко - в один захід. Однак клас бетону не завжди забезпечує довговічність конструкції з цього бетону, тому для таких конструкцій дуже важливий підбір складу бетону не тільки за міцністю, а також і за деформативністю.

Уявлення про механізм деформування цементного каменю, а значить, і бетону, на стадії пружного стиснення і повзучості, що швидко натікає, важливі для дослідження прогинів залізобетонних конструкцій, що згинаються, при невеликих габаритах, а також при дослідженнях залізобетонних довгомірних конструкцій, при яких тривалість одного циклу досліджень складає від 10 до 15 хвилин. На рис. 1, а зображена діаграма стиснення, а на рис. 1, б - кінетика деформування зразка.

Формулювання мети. Дослідити міцнісні та деформативні властивості бетону, а також підібрати оптимальний склад бетону, що забезпечує довговічність і недеформованість для монолітного перекриття.

Основний матеріал. Довговічність самого перекриття буде залежати не тільки від класу бетону, а також від такого фактора, як повзучість.

Про величину границі тривалої міцності бетону, а також і впливу на нього різних факторів до теперішнього часу не було єдиної думки. Для практичної мети значення відносної границі тривалої міцності важкого бетону приймається рівним $0,8 f_{\text {cd }}$ незалежно від технічних параметрів, які характеризують конкретні 
властивості бетону. Таке ж схоже зниження також спостерігається й для тривалої міцності бетону при розтягненні.

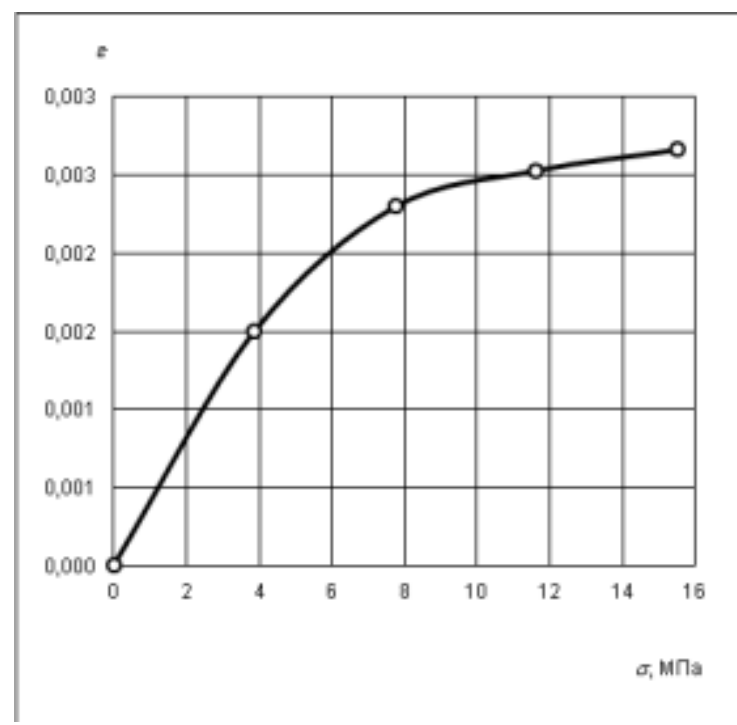

б)

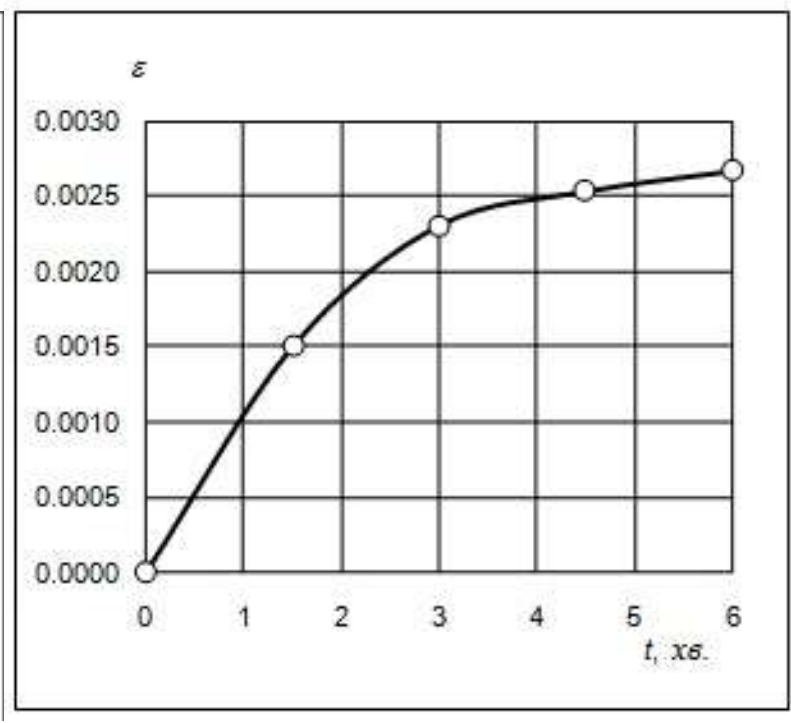

Рис. 1. Залежність від носної деформації $\varepsilon$ призматичного зразка розміром $10 \times 10 \times 40 \mathrm{~cm}$ цементного каменю з $В / Ц=0,4$ від:

a - стискальної напруги $\sigma$ при короткочасному навантажуванні (до 6 хв);

б - часу (кінетика деформування) при короткочасному навантажуванні

Проміжок часу, протягом якого деякий зразок починає руйнуватися під навантаженням, залежить від величини докладених до нього напруг: збільшення напруг призводить до зменшення часу до того моменту, коли він починає руйнуватися. Проведена неодноразова перевірка показала, що деформації в межах таких напруг і такого часу дії навантаження були оборотними і зникали при знятті навантаження. Останнє дозволяє віднести ці деформації не тільки до пружних, але й до деформацій в'язкісної чи пластичної течії.

Більш повільні й набагато більші, ніж миттєві пружні, ці деформації необхідно віднести до еластичних деформацій, а якщо бути точними, то до високоеластичних, які протікають протягом часток секунд, i повільних, таких, що протікають кілька хвилин.

Деформація цементного каменю при його короткочасному стисканні $з$ першого погляду криється у сполученні швидких деформацій стискання гелевих частинок у тонких прошарках між цементними частинками й дифузійного переносу проти іонів і гідратованої ними води, що здійснюється 3 прошарків у максимально віддалену й найменш напружену зону між цементними частинками. У зв'язку з цим будемо розрізняти гель у прошарках між цементними частинками і гель в об'ємі між цементними частинками.

Деформації бетону, тривалість яких обчислюється хвилинами або десятками хвилин, у нормативній літературі визначаються так само, як деформації повзучості, що швидко натікає. А значить, повільні еластичні деформації цементного каменю $\epsilon$ результатом деформації повзучості, що швидко натікає. Вони проявляються при випробуванні зразків на міцність, при передачі попередньої напруги на бетон попередньо напружених 
залізобетонних виробів, при проходженні залізничного й автомобільного транспорту по мостах i тунелях, при пересуванні вантажопідйомних кранів по підкранових балках, відносно повільно зникаючи при знятті навантаження, та ін.

При розгляді деформацій цементного каменю й бетону при їхньому короткочасному навантаженні i 3 метою використання на практиці будемо виділяти дві стадії деформування:

- стадію пружного стиснення, що протікає протягом часток секунд і відповідає швидкій високоеластичній деформації;

- стадію повзучості, що швидко натікає, яка протікає протягом кількох хвилин або десятків хвилин і відповідає повільній високоеластичній деформації.

У результаті досліджень цементного каменю (проведених в УкрДАЗТ) при тривалій і довгочасній дії навантаження отримані деякі графіки зміни відносних деформацій у часі, які охопили як тривалу до 150 діб (рис. 2, а), так і довгочасну до 900 діб (рис. 2, б) і більше діб, дію навантаження. a)

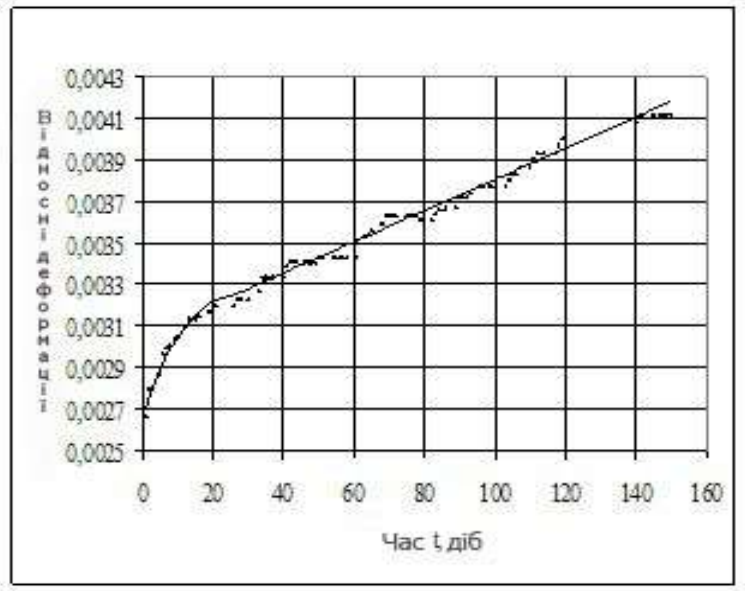

б)

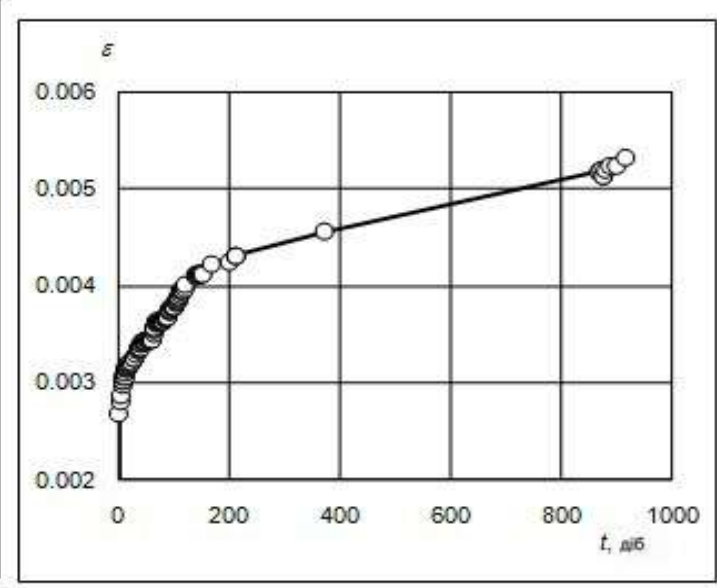

Рис. 2. Залежність відносної деформації $\varepsilon$ звичайної повзучості цементного каменю

(призма $10 \times 10 \times 40 \mathrm{~cm}, B / Ц=0,4$, нормальні умови твердіння) від часу при напрузі стиснення 15,2 МПа. Точки - експериментальні дані: а - суцільна лінія - графік залежності, що пропонується; б - суцільна лінія -за запропонованими рівняннями

Згідно з проведеними дослідженнями, період довгочасної дії навантаження відрізняється тим, що на ньому виділяється ще одна лінійно-похила ділянка 3 більш низькою швидкістю й більшою тривалістю понад 750 діб. Прояв двох ділянок, які різко відрізняються за швидкістю й тривалістю деформування, і врахування того, що перша похила ділянка за своєю тривалістю близька до повзучості, що звичайно спостерігається, а друга лінійна ділянка в дослідженнях повзучості раніше не відмічалася, дає підставу виділити в деформаціях повзучості при довгочасному навантаженні зразків із цементного каменю, крім звичайної, стадію довгочасної повзучості, яка настає після звичайної.

Підбір складу бетону для монолітного перекриття грунтується на відомих закономірностях, врахованих НДІЗБДержбуду СРСР у «Руководстве по подбору составов тяжелого бетона»:

- законі міцності (водоцементного відношення) - міцність бетону $f_{c d}$, МПа, залежить від водоцементного відношення В/Ц зворотно пропорційно: 


$$
f_{c d} \sim 1 /(B / Ц)
$$

- законі водопотрібності - легкоукладальність бетонної суміші залежить від витрати води на $1 \mathrm{~m}^{3}$ бетону $B$, кг: рухливість (осадка конуса) $O K$, см, - прямо пропорційно, жорсткість Ж, с, - зворотно пропорційно:

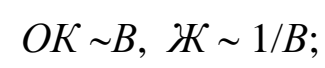

- принципі абсолютних об'ємів - сума

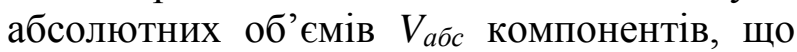
витрачаються на приготування $1 \mathrm{~m}^{3}$ щільного бетону (щебеню, піску, цементу, води), має дорівнювати $1 \mathrm{~m}^{3}$ :

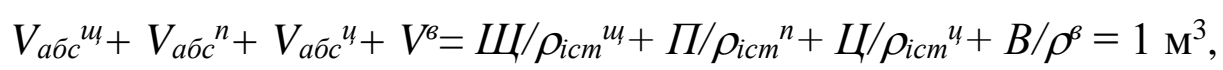

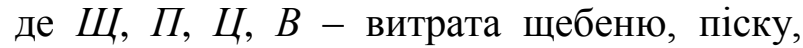
цементу і води відповідно на $1 \mathrm{~m}^{3}$ бетону, кг; $\rho_{i c m}{ }^{\mu}, \rho_{i c m}{ }^{n}, \rho_{i c m}{ }^{4}, \rho^{\beta}-\quad$ істинна густина щебеню, цементу, піску і густина води відповідно, кг/ $\mathrm{M}^{3}$;
- розсуненні зерен крупного заповнювача: коефіцієнт розсунення $\alpha$ відношення абсолютного об'єму цементнопіщаного розчину $V_{\text {unр }}$ до об'єму пустот у крупному заповнювачі $V_{n y c}{ }^{m}$ в $1 \mathrm{~m}^{3}$ бетону має бути більшим за 1:

$$
\alpha=\frac{V_{u n p}}{V_{n y c}^{u}}=\frac{\frac{\Pi}{\rho_{i c m}^{n}}+\frac{\zeta}{\rho_{i c m}^{u}}+\frac{B}{\rho^{B}}}{\frac{U Ц}{\rho_{\text {mac }}^{u}} \cdot V_{n y c}^{u}}>1,
$$

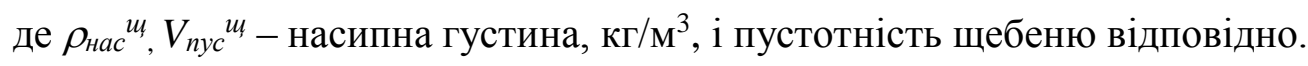

Підбір складу грунтується також на новій закономірності, встановленій в УкрДАЗТ, - залежності показників, що забезпечують надійність i довговічність конструкцій, - водонепроникності та деформативності бетону, тріщиностійкості та довготривалих деформацій конструкцій 3 нього від коефіцієнтів розсунення зерен крупного заповнювача $\alpha$ i зерен дрібного заповнювача $\mu$ (рис. 3 ).

Коефіцієнт розсунення зерен дрібного заповнювача $\mu$ - відношення абсолютного

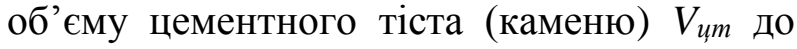
об'єму пустот у дрібному заповнювачі $V_{n y c}{ }^{n}, 1 \mathrm{~m}^{3}$ :

$$
\mu=\frac{V_{u m}}{V_{n y c}^{n}}=\frac{\frac{U}{\rho_{i c m}^{u}}+\frac{B}{\rho^{\theta}}}{\frac{\Pi}{\rho_{H a c}^{n}} \cdot V_{n y c}^{n}},
$$

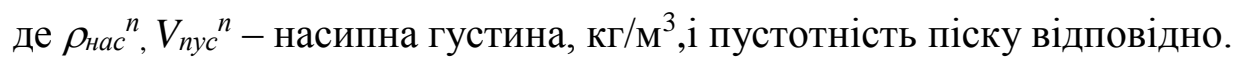




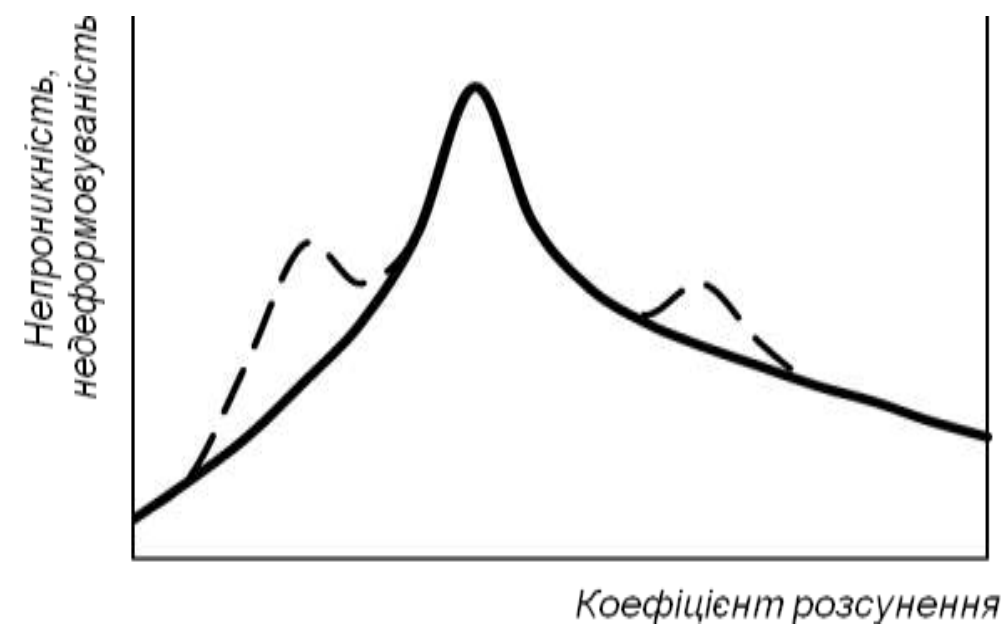

Рис. 3. Загальний вигляд залежності непроникності, недеформовуваності та інших характеристик бетону від коефіцієнтів розсунення $\alpha$ і $\mu$

Теоретичними та експериментальними дослідженнями встановлено, що залежності водонепроникності, деформативності бетону, в тому числі здатності піддаватись повзучості, а також тріщиностійкості і довготривалих деформацій конструкцій 3 нього від коефіцієнтів розсунення $\alpha$ і $\mu$ має екстремальний характер (рис. 3). Залежно від властивостей компонентів бетону існують оптимальні значення коефіцієнтів розсунення $\alpha_{\text {onm }}$ і $\mu_{\text {onm }}$, яким відповідають максимальна водонепроникність i мінімальна деформативність бетону, а також максимальна тріщиностійкість i мінімальні довготривалі деформації конструкцій 3 нього. Така залежність виявлена при дослідженнях водонепроникності тріщиностійкості бетону, попередньо напружених шпал, довготривалих деформацій від повзучості бетону довгомірних мостових прогонових споруд і тонкостінних ємнісних споруд.

Найбільш сприятливі показники вказаних властивостей бетону i конструкцій 3 нього при оптимальних

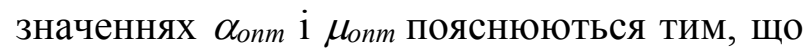
їм відповідає найщільніша упаковка одного ряду зерен дрібного заповнювача в прошарках між зернами крупного заповнювача $\mathrm{i}$ цементних частин - між зернами дрібного заповнювача (рис. 4). При цьому водонепроникність $є$ максимальною завдяки мінімальній кількості некапілярних i капілярних пор у міжзернових пустотах між зернами та частинками, а деформативність $\epsilon$ мінімальною завдяки максимальним жорсткості каркасу із твердих частинок i кількості міцних міжчасткових контактів в означених прошарках.

Оптимальні значення коефіцієнтів розсунення $\alpha_{\text {опm }}$ i $\mu_{\text {опm }}$ залежать від середнього розміру визначальної фракції зерен крупного і дрібного заповнювача й частинок цементу $d_{u}, d_{\Pi}, d_{u}$, мМ, відповідно, i визначаються аналітичним шляхом за даними про їх гранулометричний склад.

Виходячи із викладеного, для забезпечення надійності й довговічності конструкцій склад бетону підбирається 3 урахуванням оптимальних значень коефіцієнтів розсунення зерен крупного й дрібного заповнювача $\alpha_{o n m}$ і $\mu_{\text {onm. }}$. 
a)

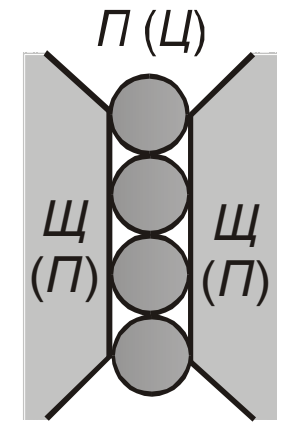

$\Pi(\lfloor)$

б)

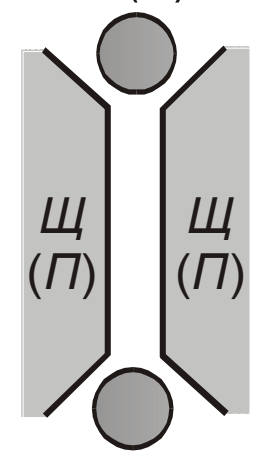

в)

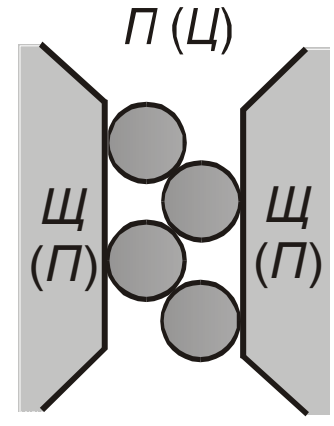

Рис. 4. Схеми упаковки зерен піску або цементу в прошарках між зернами щебеню або піску, відповідно: а - при оптимальних значеннях $\alpha_{\text {onm }}$ i $\mu_{\text {оnm }}$,

$\sigma, в-$ при неоптимальних значеннях $\alpha$ i $\mu$

Величина граничних деформацій повзучості цементного каменю в бетоні залежить від вмісту цементного каменю в ньому та його структурних характеристик або коефіцієнтів розсунення зерен піску й щебеню. Геометричний смисл зв'язку оптимальних коефіцієнтів розсунення зерен піску $\mu_{\text {onm }}$ та щебеню $\alpha_{\text {оnm }}$ виражається рівняннями:

$$
\begin{aligned}
& \alpha_{\text {onm }}=2,1 \cdot\left(1+\frac{d_{n}}{d_{u}}\right)^{3}-1,1, \\
& \mu_{\text {onm }}=2,1 \cdot\left(1+\frac{d_{u}}{d_{n}}\right)^{3}-1,1 .
\end{aligned}
$$

Визначають витрату щебеню, кг $/ \mathrm{M}^{3}$ :

$$
Щ=\frac{1}{\frac{\alpha_{\text {onm }}}{\rho_{\text {Hac }}^{u}} \Pi y c^{u}+\frac{1}{\rho_{i c m}^{u}}} .
$$

Визначають витрату піску, кг/ $\mathrm{m}^{3}$ :

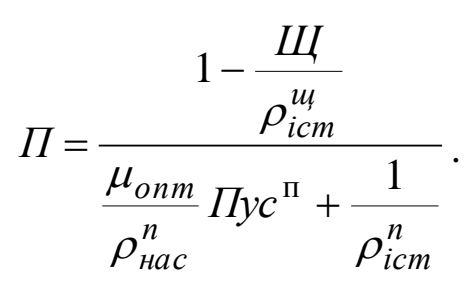

Визначають витрату води залежно від потрібної легкоукладальності за ГОСТ 10180.1 .

Визначають витрату цементу, кг $/ \mathrm{M}^{3}$ :

$$
Ц=\rho_{i c m}^{u} \cdot\left(1-\frac{\Psi}{\rho_{i c m}^{u}}-\frac{\Pi}{\rho_{i c m}^{n}}-\frac{B}{\rho^{B}}\right) .
$$

Висновки. Основним аспектом практичної значимості розроблених уявлень про довгочасну повзучість бетону $\epsilon$ встановлення кількісного взаємозв'язку деформацій i кінетики довгочасної повзучості зі структурою бетону та його дійсними й оптимальними характеристиками. Визначення, врахування i направлена зміна цих характеристик дозволить використовувати вказані залежності для покращення прогнозу, нормування й контролю деформацій повзучості залізобетонних виробів i конструкцій для створення бетонів для виготовлення й ремонту монолітних конструкцій. 


\section{Список використаних джерел}

1. Плугин, А.Н. Коллоидно-химические основы прочности, разрушения и долговечности бетона и железобетонных конструкций [Текст] / А.Н. Плугин, А.А. Плугин, О.А. Калинин // Цемент. - 1997. - № 2. - С. 28-32.

2. Плугин, А.Н. Электрогетерогенные взаимодействия при твердении цементных вяжущих [Текст]: дисс. ... д-ра хим. наук: 02.00.11 / А.Н. Плугин. - Защищена 14.06.1989; утв. 20.10.1989. - К.: ИКХХВ, 1989. - 282 с.

3. Понаднормативна довгочасна повзучість бетону в залізобетонній конструкції місткісної споруди [Текст] / А.А. Плугін, А.М. Плугін, С.М. Кудренко, Д.А. Плугін // Проблеми надійності та довговічності інженерних споруд і будівель на залізничному транспорті: зб. наук. праць. - Харків: ХарДАЗТ, 1999. - Вип. 37. - С. 32-44.

4. Эксплуатационные исследования деформационных характеристик тонкостенной железобетонной конструкции ванны бассейна «Локомотив» в г. Харькове [Текст] / А.А. Плугин, А.Н. Плугин, С.Н. Кудренко, Д.А. Плугин, О.А. Калинин // Залізничний транспорт України. - 2001. - № 3 (24). - С. 25-27.

5. Мірошніченко, С.В. Дослідження напруг і деформацій у плитах без балластного мостового полотна [Текст] / С.В. Мірошніченко // Зб. наук. праць. - Харків: УкрДАЗТ, 2009. Вип. 109. - С. 113-119.

6. Лютый, В.А. Повторяющаяся быстронатекающая ползучесть бутовой кладки мостовых опор при механоэлекрических воздействиях [Текст]: дисс. ... канд. техн. наук. Харьков: УкрГАЖТ. - 2007. - 201 с.

7. Спосіб визначення складу високоміцного, тріщиностійкого і водонепроникного бетону [Текст]: деклараційний патент UA 62613 А А.М. Плугін, О.А. Калінін, С.В. Мирошниченко, А.А. Плугін [та ін.]; опубл. 2003, Бюл. № 12.

Рецензент д-р техн. наук, професор А.А. Плугін

Коломієць Наталія Олександрівна, слухач ІППК, гр. МЗ-ПЦБ-Б-11.

Гребенщикова Катерина Сергіївна.

Мірошніченко Сергій Валерійович, канд. техн. наук, доцент кафедри будівельних матеріалів, конструкцій та споруд.

Kolomyjec N.A., Hrebyenschykova K.S., cand. of techn. scinces Miroshnichenko S.V. 